\title{
RELASI ISLAM DAN KEBEBASAN: TELAAH ATAS PEMIKIRAN ULIL ABSHAR ABDALLA
}

\author{
Oleh: Taufani \\ Ketua Jurusan Sosiologi Agama \\ Fakultas Ilmu Sosial dan Ilmu Politik \\ IAIN Manado
}

\begin{abstract}
:
This writing focuses on Ulil Abshar Abdallah's thoughts on the relation of freedom and Islam. The purpose of this paper is to find out how Ulil Abshar Abdallah regards the freedom that is related to the Islamic's perpective which has been seen as the alien with the view of freedom. This method of writing is done by using a qualitative approach and the analysis model is descriptive analysis. The existing data is collected by library research by reading the literatures related to Ulil Abshar Abdalla's thoughts. The results of this paper explains that the freedom for Indonesian society is contrary to the teachings of Islam because they still interpret the teachings are limited to the text. the worship of Islamic texts is still very strong in the life of Indonesian society in general. This outward attitude of dogmatism can be pursued by recontextualizing interpretations that are in line with the real development of humanity today.
\end{abstract}

\section{Key words: \\ Islam, Freedom, Ulil Abshar Abdalla}

\section{PENDAHULUAN}

Paska jatuhnya Soeharto dari tampuk kepemimpinan pada tahun 1998 yang dimotori oleh kalangan masyarakat sipil, khususnya kalangan mahasiswa, Indonesia mengalami berbagai perubahan signifikan,salah satunya ialah perubahan pada lanskap politik. Pada zaman Orde Baru yang dipimpin oleh Soeharto, hampir tak ada celah kebebasan untuk berpendapat dan berekspresi, karena rezim yang berkuasa cenderung bersifat otoriter dan militeristik.Siapapun yang berani mengkritik kebijakan rezim dan melakukan demonstrasi di ruang publik, maka rezim tak segan menangkap, menjebloskan, bahkan menyiksa pelaku aksi tersebut karena dianggap menjadi penghambat pembangunan, anti-Pancasila, atau tidak pancasilais.

Setelah munculnya era reformasi yang merupakan antitesis dari zaman Orde Baru, gerakan masyarakat sipil menjadi tumbuh subur, ditandai dengan lahirnya berbagaiwadah dan juga organisasi kemasyarakatanyang konsen di berbagai bidang. Sebagian dari gerakan tersebut memfokuskan diri pada proses edukatif di masyarakat dengan mengusung berbagai tema-tema kontemporer, seperti HAM, demokrasi, dan pluralisme melalui seminar, pelatihan, danpublikasi. Dalam konteks inilah, kehadiran Jaringan Islam Liberal (JIL) menjadi relevan untuk diperbincangkan.JIL hadir meramaikan berbagai wacana modern yang tumbuh dan 
berkembang pasca Orde Baru. Di sisi lain, ia juga hadir sebagai respon terhadap menguatnya radikalisme agama yang di waktu bersamaan juga ikut tumbuh subur.

Salah satu tokoh penting dalam JIL yang pemikirannya menarik untuk kita diskusikan kali iniialah Ulil Abshar Abdalla.Ia merupakan salah satu tokoh awal yang merintis pendirian JIL. Ulil adalah satu dari sekian tokoh di JIL yang pemikirannya paling mengundang kontroversi.Tulisan ini hadir untuk mendiskusikan pandangan Ulil tentang Islam dan kebebasan.Selama ini ada kesan yang muncul khususnya dari Barat, bahwa Islam adalah sebuah agama yang kontrapada kebebasan dan anti pada modernitas.Oleh karena itu, pemikiran Ulil mengenai Islam dan kebebasan menjadi menarik dan relevan untuk ditelaah.

\section{PEMBAHASAN}

\section{Ulil dan Kehidupan yang Mengitarinya}

Ulil Abshar Abdalla adalah seorang cendekiawan muslim atau lebih dikenal sebagai salah satu tokoh pendiri Jaringan Islam Liberal (JIL). Ulil lahir di Pati, Jawa Tengah pada tanggal 11 Januari 1967. Ayahnya, Abdullah Rifa'i adalah pengelola pesantren Mansajul Ulum di Pati.Ulil mengakui bahwa ayahnya adalah sosok yang cukup keras dalam mendidik santrinya. Namun, Ulil berterima kasih pada sikap ayahnya tersebut karena dari didikan itulah, ia dapat menguasai tata bahasa Arab (nahwu), bidang yang menjadi keahlian ayahnya.

Ulil menyelesaikan pendidikan menengahnya di Madrasah Mathali'ul Falah, Kajen, Pati, Jawa Tengah yang diasuh olehAlm.K.H. M. Ahmad Sahal Mahfudz (Mantan Ketua MUI dan juga tokoh Nadhlatul Ulama). Ketika menempuh pendidikan di Madrasah, Ulil memiliki ketertarikan yang cukup besar pada bidang sastra Indonesia.Dapat dikatakan, bahwa Ulil adalah seorang sosok yang memiliki kultursantriyang cukupkentalkarena sejak kecil hinggamenempuh sekolah menengah,ia banyak bersentuhan dengan tradisi pendidikan keagamaan, sesuatu yang menjadi ciri khaskalangan Nadhlatul Ulama (NU).Akibat persentuhannya tersebut, Ulil dapatmengakses berbagailiteratur Islam klasik.

Ulil mendapat gelar sarjananya di Fakultas Syari'ah LIPIA (Lembaga Ilmu Pengetahuan Islam dan Arab) Jakarta. LIPIA merupakan cabang dari Universitas Islam Muhammad Ibnu Sa'ud di Riyadh, Arab Saudi.Dalam operasionalnya, LIPIA banyak mendapatkan bantuan dana segar dari Arab Saudi. LIPIA banyak berkontribusi dalam memperkenalkan gagasan pemikiran daritokoh-tokoh Ikhwanul Muslimin di Indonesia melalui pengajar-pengajarnya yang memiliki latar belakang Ikhwan yang sangat kental dan juga dari penerjemahan buku-buku karya intelektual Ikhwanul Muslimin. Selain mempromosikan ide-ide Ikhwanul Muslimin, kurikulum di LIPIA juga banyak mempromosikan pemikiran Islam salafi-wahabi, termasuk pemikiran Ibnu Taimiyah, yang merupakan cirikhas pemikiran Islam di Arab Saudi. ${ }^{1}$

Ulil juga pernah mengenyam pendidikan di Sekolah Tinggi Filsafat (STF) Driyarkara. Boleh jadi karena persentuhannya denganpendidikan filsafat di STF Drikarya, maka hal itu ikut membentuk pandangan keagamaan Ulil menjadi sangat kritis dan rasional dalam 
memaknai teks-teks agama.Ulil lalu melanjutkan studi Doktoral-nya di Boston University, Amerika Serikat. Dalam proses studinya di Amerika, Ulil dengan mudah mengakses berbagai karya intelektual yang dating dari berbagai tradisi pemikiran karena ia memiliki kemampuan bahasa Inggris dan juga bahasa Arab yang cukup baik.

Di Indonesia, Ulil dikenal sebagai salah satu tokoh cendekiawan muda muslimyang mempelopori pembentukan Jaringan Islam Liberal (JIL). JIL adalah suatu wadah atau jaringan yang terdiri dari kumpulan anak-anak muda yang memiliki gairah intelektual yang tinggi. Mereka pada umumnya adalah anak-anak muda yang berlatar belakang NU, mahasiswa UIN Ciputat, dan juga berlatar belakang sebagai aktivis dan akademisi. Mereka pada umumnya tidak hanya menguasai kitab kuning, namun juga menguasai "kitab putih" yang identik denganilmu-ilmu modern, seperti ilmu politik, filsafat, sosiologi, antropologi, dll.Beberapa nama, seperti Budi Munawar Rachman, Saiful Mujani, Ahmad Sahal, Luthfi Assyaukanie, Ikhsan Ali Fauzi, Rizal Panggabean, dan Rizal Mallarangengmerupakanbeberapa tokoh yang terjun mengusung gerbong Islam Liberal di Indonesia bersama Ulil.

Dalam aktivitasnya di JIL, Ulil seringmenuai simpatiyang cukup besar, khususnya dari kalangan anak muda karena ia hadir membawa pandangan yang cukup segar dan progresifdi tengah kegersangan dan kejumudan intelektual yang melingkupi umat Islam. Namun, Ulil juga kerapmenuai berbagai kritik tajam hingga ancaman pembunuhan oleh kelompokkelompok yang anti pada pemikirannya.Pemikiran Ulil sering dianggap menyimpang dan "nyeleneh"karena ia sering melontarkan gagasan yang cukup asing dan bertentangan dengan apa yang selama ini dipahami oleh mayoritas umat Islam di Indonesia. Namun, Ulil tak menghiraukan itu.Ia tetap saja teguh pada pendiriannya.

Dalam berbagai kesempatan,Ulil kerap mendiseminasi gagasan keislamannya baik melalui media elektronik, cetak, maupun melalui forum diskusi dan seminar.Ciri khas pemikiran Ulil adalah penekananya pada perlunya pembaharuan pemikiran Islam dan juga penafsiran ulang terhadap hukum Tuhan agar dapatmerespon tuntutanperkembangan zaman.Atas kiprahnya tersebut, Ulil sering disebut sebagai pewaris pembaharu pemikiran Islam di Indonesia setelah Cak Nur.

Belakangan ini, Ulil yang merupakan menantu budayawan dan tokoh senior NU, K.H. Mustofa Bisri,menyibukkan diri untuk menjadi seorang politikus di Partai Demokrat.Namun sebelum aktif sebagai politikus, Ulil pernah menjadi Ketua Lakpesdam (Lembaga Kajian dan Pengembangan Sumber Daya Manusia) Nahdlatul Ulama, sekaligus juga menjadi staf peneliti di Institut Studi Arus Informasi (ISAI). Ia juga pernah menjabat sebagai Direktur Program Indonesian Conference on Religion and Peace (ICRP) dan juga Direktur Freedom Institute di Jakarta. 


\section{Ulil dan Kontroversinya}

Sosok Ulil,di Indonesia, dikenal sebagai sosok yang penuh dengan kontroversi akibat pandangan keislamannya yang dianggap cukup berani melawan arus. Titik awal kontroversi Ulil adalah ketika ia bersama rekan-rekannya mendirikan Jaringan Islam Liberal(JIL) pada tahun 2001. Ia mendirikan JIL karena dua alasan utama. Pertama, Ulil melihatbahwa pasca reformasi terjadikecenderungan keagamaan yang fundamentalistis, radikal, dan pro terhadap kekerasan.Untuk itulah JIL hadir sebagai kritik terhadap munculnya kecenderungan tersebut.Kedua, JIL hadir untuk mendiseminasi ajaran Islam yang rasional, kontekstual, humanis, dan pluralis, sehingga dapat relevan dengan realitas sosial yang selalu berubahubah. ${ }^{2}$ Penggunaanterm liberaldipakaikarena ia diartikan sebagai kebebasan dan pembebasan dari kungkungan pemahaman klasik yang kaku, kolot, jumud, dan tidak sesuai dengan perkembangan zaman. ${ }^{3}$

Sebenarnya penggunaan term liberal dalam wacana keislaman bukanlah hal baru di Indonesia.Jauh sebelum Ulil dan rekan-rekannyamemperkenalkan gagasan Islam liberal, setidaknya dua tokoh pemikir Islam Indonesia, Harun Nasution dan Nurcholish Madjid (Cak Nur) telahmenggunakanterm tersebut dalam tulisannya.Pada tahun 1970-an, Harun Nasution memperkenalkan kembalialiran Mu'tazilah, suatu aliran yang pernah berjaya di masa kejayaanperadaban Islam dansempatterlupakandalam waktu yang cukup lama akibat konflik politik-keagamaan di masa lalu.Harun Nasution berpendapat bahwa kalangan terpelajar, khususnya mereka yang banyak mendapatkan pendidikan Barat lebih cocok menganut aliran teologi Mu'tazilah dibandingkan Assyariah karenaaliran Mu'tazilahcenderung sangatrasional dan memberikan penekanan pada penggunaan rasio atau akal. ${ }^{4}$ Karena rasionalismenya-lah, aliran Mu'tazilah dianggap sebagai aliran yang lebih banyak mempunyai corak liberal. ${ }^{5}$ Dalam perjalananya, sangat kelihatan bahwa Ulil dan rekan-rekannya di JIL sedikit banyaknya sangat dipengaruhi oleh corak pemikiran aliran Mu'tazilah yang dikenal liberal dan mempertahankan kebebasan berpikir,karena dalam berbagai penafsirannya terhadap teks keagamaan,sangat tampakkecenderungan mereka untuk memaksimalkan penggunaan akal dalam memahami dan menggali maknayang tersembunyi di balik teks.

Pada tahun 1970-an, Cak Nurtelah melontarkan gagasannya mengenai perlunya menghadirkan suatu kelompok pembaruan Islam yang liberal yang menekankan pada sikap non-tradisionalisme dan non-sektarianisme. ${ }^{6}$ Sikap non-tradisionalisme tersebut adalah kebalikan dari sikap "kami mendapatkan bapak-bapak kami berjalan di atas suatu kata, nilai, dan di atas warisan-warisan mereka itulah kami memperoleh petunjuk," sedangkan sikap nonsektarianisme adalah kebalikan dari sikap "setiap golongan bangga dengan apa yang ada padanya,"7 Untuk mewujudkan itu, lanjut Cak Nur, maka dibutuhkan kesungguhan dan keberanian untuk meninjau kembali pemaknaan kita terhadap Al-Qur'an karena AlQur'ansendiri tak pernah memberikan penjelasan secara rinci tentang segala persoalan duniawi. Oleh karena itu, penggunaan rasio atau akal-yang juga didukung dan ditunjang oleh 
spesialisasi dan metode keilmuan yang kuat dan canggih- menjadi suatu keharusan karena ia dapat membantu manusiadalam membaca gejala sosial dan sejarah.

Hanya saja, penggabunganterm Islam dan liberal menjadi problematisbagi banyak kalangan diIndonesia, karena selama ini term liberalsering dimaknai secara peyoratif yang berarti keliaran dan juga sesuatu yang berkonotasi Barat. Di mata Rizal Mallarangeng, istilah liberal (liberalisme) sering dimaknai secara negatifkarenakulturbudaya agraris, yang bersifat komunaldan paternalistik,sangat tumbuh mengakar dalam diri sebagian masyarakat Indonesia.Selain itu, sikap alergi terhadap term liberal diIndonesia terjadi karena adanya trauma historis terhadap kolonialisme yang sering dikaitkandengan kapitalisme dan liberalisme. ${ }^{8}$

Nama Ulil menjadi sangat melambung ketika iamelontarkan gagasannya dalam sebuah tulisan di Kompas tertanggal 18 November 2002yang berjudul Menyegarkan Kembali Pemahaman Islam. Dalam artikelnya tersebut, Ulilmembuka tulisannya dengan menyatakan bahwa,

"Saya meletakkan Islam pertama-tama sebagai sebuah "organisme" yang hidup; sebuah agama yang berkembang sesuai dengan denyut nadi perkembangan manusia.Islam bukan sebuah monumen mati yang dipahat pada abad ke-7 Masehi, lalu dianggap sebagai "patung" indah yang tak boleh disentuh tangan sejarah.",

Pandangan di atas tentu lahir dari adanya kegelisahan Ulil melihat praktik kejumudan dalam tubuh umat Islam, sehingga mereka mengalami ketertinggalan di hampir segala lini.Kejumudan itu terjadi karena umat Islam terlalu sibuk berkutat dengan teks agama, sehingga mereka mengabaikan pengalaman riil kemanusiaan yang selalu berubah-ubah. Dengan kata lain, Ulil ingin menegaskan bahwa terjadi pergeseran dalam tubuh umat Islam, yakni mereka lebih "menyembah teks" serta"memonumenkan ajaran Islam" dibandingkan berusaha menangkap pesan etis universal atau -menggunakan bahasa Ulil-esensi transendental dari Al Qur'an itu sendiri.

Karena adanya kecenderungan tersebut, makamuncul pandangan bahwasemakin dekat seseorang pada teks, maka semakin dekatia pada kebenaran. Sebaliknya, semakin jauh seseorang pada teks, maka semakin jauh iapada kebenaran. Dengan kata lain, tingkat kebenaran seseorang semata-mata hanya diukur dari kedekatan mereka pada teks agama. ${ }^{10}$ Untuk itulah Ulil hadir melakukan "pemberontakan" terhadap menguatnyakecenderungan "penyembahan teks" tersebut.Menurutnya,teks bukanlah suatu entitas yang berdiri sendiri, melainkan iabersinggungan langsung dengan konteks kemanusiaan yang terikat oleh partikularitas ruang dan waktu.Oleh karena itu, teks agama tanpa manusia atau masyarakat penafsir tentu tak akanpunya makna. Manusia-lah yang memiliki peran penting dalam mem-bunyi-kan dan memberi pemaknaan pada teks tersebut dengan menggunakan akal dan segala potensi yang melekat dalam dirinya, sehingga teks tersebut dapatrelevan dan sejalandengan pengalaman riil kemanusiaan. 
Untuk itu, Ulil menawarkan suatu bentuk penafsiran kembali terhadap teks keagamaan dalam perspektif yang lebih segar, yaknipertama, penafsiran harus bersifat non-literal, kontekstual, substansial, dan mampu menyesuaikan perkembangan kehidupan yang terus berubah. Kedua,penafsiran harus dapat memisahkan secara jernih unsur-unsur agama yangbersifat fundamental dan juga yang bersifatkreasi budaya setempat atau dengan kata lain penafsiran harus jeli membedakan mana yang Arab dan mana yang Islam.Ketiga, umat Islam tak boleh memandang dirinya sebagai umat yang ekslusif dan terpisah dari umat yang lainnya.Umat manusia harus bersatu di bawah nilai kemanusiaan karena nilai kemanusiaan sendiri sejalan dengan ajaran Islam.Keempat, dibutuhkan struktur sosial yang membedakan antara kekuasaan politik dan agama.Agama bersifat pribadi atau personal sehingga menjadi urusan masing-masing pemeluknya, sedangkan kehidupan publik ditentukan oleh kesepakatan bersama melalui prosedur demokrasi. ${ }^{11}$

Dengan menawarkanbentuk penafsiran tersebut, maka Ulil telahmenceburkan dirinya dalam proses desakralisasi dan dekonstruksipada doktrin yang telah mapan. Sebagai contoh, Ulil menganggap bahwa soal jilbab, potong tangan, qishash, rajam, jenggot, jubah tak wajib diikuti, karena praktik tersebut hanya ekspresi lokal partikular Islam di Arab, untuk tidak mengatakan budaya Arab.Ulil menjelaskan bahwa umat Islam tak boleh hanya berkutat pada hal-hal yang bersifat partikular, sehingga gagal menangkap inti dannilai-nilai universal yang terpendam di balik praktik itu sendiri, sebagaimana yang ia contohkan pada penggunaan jilbab. Menurutnya, inti penggunaan jilbab adalah agar manusia mengenakan pakaian yang sesuai standar kepantasan umum.Standar kepantasan umum itu sendiri bersifat fleksibel dan sesuai dengan perkembangan kebudayaan manusia. ${ }^{12}$ Sayangnya, Ulil tidak membahas lebih jauh tentang bagaimana cara mengukur standar kepantasan umum tersebut karena tentu setiap tempat akan memiliki standar kepantasan umum yang berbeda-beda.

Di samping itu, Ulil juga telah mendesakralisasi dan mendekonstruksi pandangan klasik yang mengharamkan pernikahanbeda agama, khususnya antara perempuan Islam dengan lelaki non-Islam. Dengan keberaniannya tersebut, Ulil harussiap menghadapi resistensi yang sangat kuat dari sebagian besar umat Islam, karena dalam pikiran mereka masih terpatri pandangan bahwa pernikahan beda agama bersifat haram. Namun, Ulil tetap jalan terus melanjutkan "pemberontakannya" karena ia meyakini bahwatak ada dalil dalam Al Qur'an yang melarang secara tegas praktik nikah beda agama. Ulil meyakini bahwa ajaran Islam adalah ajaran yang universal yang menjunjung tinggi harkat dan martabat manusia, tanpa melihat agamanya, sehingga pelarangan praktik pernikahanbeda agama sudah perlu ditinjau kembali karena ia bertentangan dengan nilai universal Islam.

Sebenarnya gagasan pernikahan beda agama bukanlah hal baru, karena jauh sebelum Ulil melontarkan gagasan tersebut, Cak Nur telah melakukan hal tersebut terlebih dahulu. Cak Nur menyetujui praktik nikah beda agama karena ia meyakini bahwa seluruh agama adalah Islam dalam arti yang generik, yakni sikap ketundukan pada Tuhan. ${ }^{13}$ Gagasan Cak Nur ini mempunyai implikasi positif pada munculnya paham relativisme eksternal, yakni adanya 
penghargaanyang tinggi terhadap perbedaan agama. Dengan kata lain, meskipun Islam dianggap sebagai agama yang benar, namun kebenaran Islam tak memungkiri adanya kebenaran yang dimiliki oleh agama lain. ${ }^{14}$ Dan, sangat tampak bahwa Ulil ingin melanjutkan estafet mazhab liberalyang landasan epistemologis dan teologisnya telah disiapkan oleh Cak Nur(dan tentu juga Gus Dur, Harun Nasution, dll).Hanya saja, kelemahan Ulil dalam gagasannya mengenai pernikahan beda agama adalah ia tak dapat melakukan sebuah loncatan yang lebih progresif melebihi Cak Nur. Ia hanya sekadar menggaungkan kembali wacana yang membolehkan pernikahan beda agama yang sebelumnya telah dilakukan oleh Cak Nur, namunia belum "berani”" melakukan sebuah langkah praksisyang lebih revolusioner, misalnya dengan melakukan judicial review pada Mahkamah Konstitusi (MK) agar setiap warga negara Indonesiadapat melakukan praktik nikah beda agama secara resmi dan konstitusional.Hal ini dirasa sangat penting karenapengaruh globalisasitelah mengaburkan batas-batas fisik suatu negara, sehingga perjumpaan antar individu dengan individulainnya yang memiliki identitas yang berbeda, menjadi sebuah keniscayaan.Akibatnya,pernikahan beda agama-cepat atau lambat,setuju atau tidak setuju- akan menjadi tren di masa mendatang.

Sejak kemunculan artikel Ulil di harian Kompas, nama Ulil menjadi bulan-bulanan oleh kelompok Islam radikal yang memiliki cita-cita untuk mewujudkan negara yang berlandaskan syariat Islam, seperti Front Pembela Islam (FPI), Hizbut Tahrir Indonesia (HTI), dan Majelis Mujahidin Indonesia(MMI). Berbagai tuduhan dan umpatan yang tak berdasar ditujukan padanya, seperti kafir, Yahudi, antek Zionis dan Barat, dll. Yang paling mengerikan, Ulil mendapatkan ancaman berupa fatwa mati olehAthian Ali, pimpinan Forum Ulama Umat Islam (FUUI).Darah Ulil dianggap halal untuk dibunuh karena ia dianggap telah merusakkesucianajaran Islam dan juga telahmelukai hati umat Islam. Ulil dituduh telah menghalangi penegakansyariat Islamdalam level bernegara (Islamisasi negara).Namun, Ulil tetap jalan terus dengan pendiriannya.Ulilmeyakini bahwa realitas "umat Islam"tidak pernah tunggal dan seragam.Dari dulu, frase "umat Islam"sudah sering dijadikan jualan atau jargon politikoleh para elit kelompok Islam demi sebuah kepentingan jangka pendek.

Menurut Ulil, salah satu indikator sederhanauntuk menilai apakah"umat Islam" merupakan umat yang tunggal atau sebaliknya adalah melalui mekanisme pemilu. Hampir setiap pemilu, umat Islam lebih cenderung memilih partai nasionalis dibandingkan partai Islam.Dengan kata lain, setiap diadakannya perhelatan pemilu, partai nasionalis selalu keluar menjadi pemenang.Ironisnya, partai Islam itu sendiri terpecah-pecah dalam derivat-derivat kecil yang kian rumit, sehingga kekuatannya semakin hari semakin menyusut.Ulil tiba pada suatu kesimpulan bahwa meskipun umat Islam merupakan umat mayoritas di Indonesia, namun mereka tak sepenuhnyapadu menggunakan Islam sebagai landasan politik mereka. ${ }^{15}$

Di tengah kuatnyahantaman yang menerpa Ulil,Abdurrahman Wahid (Gus Dur) hadir membelaUlil melalui sebuah artikel yang berjudul "Ulil dengan Liberalismenya". Menurut Gus Dur, umat Islam tak perlu terburu-buru memberi cap kafir pada Ulil karena ia sendiri adalah seorang muslim. Gus Dur mengutip sebuah sabda Nabi Muhammad: "Barangsiapa 
yang mengkafirkan saudara yang beragama Islam, justru ialah yang kafir (man kaffara akhahu musliman fahuwa kafirun)," untuk mengingatkan mereka yang mengkafirkan Ulil. Menurut Gus Dur, pengkafiran terhadap Ulil bukanlah sesuatu hal yang baru dalam Islam. Sebelumnya, Ibnu Rusyd (Averroes)juga pernah dikafirkan oleh mereka yang berpikir sempit karena ia membela kebebasan berpikir. Jadi, menurut Gus Dur, selalu ada kesenjangan yang lebar antara penganut paham serba tertulis (ahl al-naql) dan penganut paham serba akal/rasionalis (ahl al-aqli). ${ }^{16}$

Namun Gus Dur menyadari bahwa"kesalahan" Ulil dalam pandangannyaadalah karena iamenentang pandangan mapan yang menyatakan bahwa "Telah kusempurnakan bagi kalian agama kalian hari ini (al-yauma akmaltu lakum dinakum)" (QS. Al-Maidah/ 5: 3) dan juga "Masuklah ke dalam Islam / kedamaian secara menyeluruh (udkhulu fi al-silmi kaffah)" (QS. Al-Baqarah/ 2: 208), yang oleh sebagian umat Islam diyakini sebagai bentuk kesempurnaan ajaran Islam, sehingga kebebasan berpikir dianggap tidak relevan lagi.Padahal, yang dimaksud oleh kedua ayat tersebut adalah kesempurnaan Islam dalam hal prinsip-prinsip kebenaran, bukan pada perinciannya. ${ }^{17}$ Atas dasar itulah, Ulil berani mengembangkanliberalisasi dalam pemikirannya, karena iamemiliki pemahamanbahasa Arab yang baik dan juga pengetahuan keislaman yang komprehensif, yangbelum tentu dimiliki oleh para pengkritiknya.

Lanjut Gus Dur, iamemahami alasan di balik aksi Ulil tersebut. Ulilkhawatirpandangan keras dan radikal menjadi dominan dalam pemikiran umat Islam.Selain itu, Ulil ingin agar kaum Muslim yang selama ini terpinggirkan merasa nyaman dengan pemahaman yang mereka yakini.Membatasi kebebasan berpikir yang dilakukan oleh Ulil - demikian Gus Dur- sama saja dengan menutup diri dari proses modernisasi, yang akan berakibat pada munculnya radikalisme. Radikalisme inilah yang menjadi akar lahirnya terorisme. $^{18}$

\section{Islam dan Kebebasan di Mata Ulil}

Islam adalah sebuah agama yang memberikanpandangan optimistis pada kebebasan.Menurut Ulil, kebebasan dalam Islam memiliki landasan teologis dan historis. Pertama, Islam memberikan prinsip kebebasan dalam Al-Qur'an, seperti "tidak ada paksaan dalam beragama (la ikraha fiddin)"(QS. Al-Baqarah/ 2: 256) dan "Barangsiapa mau, dia boleh beriman; kalau tidak mau beriman tidak apa-apa (fa man syaa fal yu'min wa man syaa falyakfur)" (QS. Al-Kahf/ 18: 29).Kedua, sejarah Nabi Muhammad adalah sejarah yang dipenuhi dengan penindasan.Ketika Nabi berada di Makkah, ia mengalami ancaman, tekanan, dan penolakan dari warga Mekkah.Atas dasar itulah, Nabi berhijrah ke Madinah demi mendapatkan kebebasan, karena di Mekkah ia tidak mendapatkannya.Dengan latar belakang itulah, Islam muncul menjadi agama yang sangat menghormati kebebasan. ${ }^{19}$

Dalam sejarah awal Islam, Nabi sering terlibat dalam jihad, namun jihad yang dilakukan oleh Nabi bukanlah jihad yang selama ini dimaknai sebagai perang suci melawan agama lain. Jihad yang dilakukan Nabi adalah perjuangan melawan penindasan demi 
memperoleh angin kebebasan dan juga untuk menegakkan prinsip tentang tak adanya paksaan dalam beragama. ${ }^{20}$ Namun sayangnya, ketika Islam telah menjadi mapan, umatnya secara perlahan berubah menjadi penindas.Sampai saat ini, hal tersebut masih saja terjadi. Sebagian umat Islam masih sajamenindas bahkan tak segan-segan membunuhorang lain hanya karena pandangan mereka dianggap menyimpang dari apa yang diyakini oleh kelompoknya.

Menurut Ulil, kebebasan adalah sebuah prinsip yang menempatkan manusia sebagai subyek yang bertanggung jawab penuh terhadap dirinya. Karena tanggung jawab itulah, setiap individu bebas menentukan kehendaknya, namun ia tetap harus bertanggung jawabterhadap apa yang ia kerjakan. Sebagai subyek yang yang sadar dan memiliki tanggung jawab, maka ia tak bolehdipaksa.Jadi,dalam suatu kebebasan terdapat suatu tanggung jawab. ${ }^{21}$

Lanjut Ulil, mereka yang melaksanakan kewajiban agama dalam keadaan terpaksa, maka tindakannya tidak punya nilai. Misalnya, bila seseorang dipaksa untuk mengingkari Tuhan dan iaterpaksa melakukan itu, maka ia tidak berdosa. Hal ini memiliki preseden sejarah di mana ada seorang sahabat yang bernama Ammar bin Yasirdatang menemui Nabi untuk melaporkan tindakannyayang telah mengucapkan suatu kalimat yang bertentangan dengan tauhid. Hal ini terpaksa ia lakukan karena mendapat tekanandari masyarakat Mekkah. Namun, Nabi menganggap bahwatindakan Ammar itu tidak berdosaselama ia masih memiliki iman di dalam dirinya.

Sayangnya, pandangan tentang kebebasan (liberalisme) masih sering dimaknai secaranegatif oleh sebagian umat Islam Indonesia, khususnya pasca keluarnya fatwa Majelis Ulama Indonesia (MUI) yang mengharamkan sekularisme, pluralisme, dan liberalisme.Ulil mengkritikpemaknaan MUI terhadap liberalismekarena MUI cenderung memaknainya dengan padanan kata ibahiyahatau paham kebebasan yang tanpa batas (keliaran). Oleh karena itu, Ulil menganggap bahwapemaknaan terhadap liberalismetersebut sudah sepatutnya ditinjaukembali,kebebasan itu sendiri tetap harus dibatasi oleh hukum.Kebebasan dan hukum harus saling melengkapi karena kebebasan yang tidak dilengkapi dengan hukum akan melahirkankekacauan dalam masyarakat.Ulil mengambil contoh pada negara-negara Eropa.Meskipun dikenal liberal, namun masyarakatnya hidup sangat bersih, disiplin, dan teratur.Kenapa?karena hukum yang berlaku di dalamnya sangat tegas dan ketat dibandingkan dengan hukum yangditerapkan di negara-negara yang dihuni oleh mayoritas Islam.

Sejauh ini, negeri-negeri yang mayoritas penduduknya beragama Islam, khususnya yang berada di Timur Tengah,cenderung berada di bawah kungkunganrezim pemerintahan yang otoriter dan despotik.Kebebasan individu menjadi dikekang.Tak jarang, rezim yang berkuasa sering memanfaatkan berbagaisimbol-simbol agama demi melegitimasiaksi kotornya.Untuk itulah,demi menghindari hal tersebut, maka umat Islam sudah saatnya saling bahu-membahu memperjuangkan penegakan sistem demokrasi karenasistem ini menjamin adanya kebebasan bagi setiap individu.

Demokrasi memang bukanlah suatu sistem yang sempurna, namun demokrasi jauh lebih baik dibandingkan sistem-sistem lain karena iamenempatkan manusia sebagai individu 
yang bebasdalam mengaktualisasidiri, sehingga sangatsejalan dengan nilai ideal Islam yang menyatakan bahwa "sesungguhnya Aku (Tuhan) memuliakan anak cucu Adam (manusia) (wa laqad karamna bani adam)" (QS.Al-Isra/ 17: 70). Dikatakan demikian, karena di alam demokrasi, setiap manusia diberi kebebasan untuk menentukan kehendaknya, namun iatetapdibatasi oleh aturanyang didasarkan pada hasil konsensus bersama.Di alam demokrasi, pilihan beragama menjadi tanggung jawab setiap individu.Persoalan agama menjadi persoalan privat antara individu dengan Tuhan.Negara tak punya wewenang untuk mengintervensi keyakinan suatu individu sebagaimana yang terjadi di negara yang berlandaskan hukum agama(teokrasi).

Umat Islam patut memperjuangkan sistem demokrasi karena sistem tersebut memberikan ruang bagisetiap individu untuk terlibat dalam pemecahan setiap persoalan masyarakat.Selama ini, sistem demokrasi masihsering dianggap sebagai sistem yang asing dalam Islam.Oleh kelompok Islam radikal,sistem inidianggap sebagai sistem kufur yang berasal dari negeri Barat, sehingga tak patut dijadikansebagai sistem alternatif oleh umat Islam.Kelompok Islam radikalmeyakini bahwa ajaran Islam, khususnyayang termaktub dalam Al-Qur'an dan Hadismerupakanajaran yang telah sempurna dan komplit sehinggaia dapat berfungsi sebagai obat mujarab bagi seluruh persoalan kehidupan.Dengan kata lain, meminjam pernyataan Ulil, bahwa "syariat adalah suatu "paket lengkap" yang sudah jadi, suatu resep dari Tuhan untuk menyelesaikan masalah di segala zaman."22 Oleh karena itu, para kelompok Islam radikal meyakinibahwa penegakan syariat Islam (hukum Tuhan) dalam level negara menjadi suatu kewajiban mutlak.

Namun, Ulil tak menyetujui pandangan kelompok Islam radikal tersebut karena ia meyakini, bahwa tak ada perintah dalam ajaran Islam yang menganjurkan didirikannya negara Islam.Ia lebih lanjut menyatakan, bahwa:

"Misi Islam yang saya anggap paling penting sekarang adalah bagaimana menegakkan keadilan di muka Bumi, terutama di bidang politik dan ekonomi (tentu juga di bidang budaya), bukan menegakkan jilbab, mengurung kembali perempuan, memelihara jenggot, memendekkan ujung celana, dan tetek bengek masalah yang menurut saya amat bersifat furu'iyyah. Keadilan itu tidak bisa hanya dikhotbahkan, tetapi harus diwujudkan dalam bentuk sistem dan aturan main, undang-undang, dan sebagainya, dan diwujudkan dalam perbuatan.",23

Sejauh ini, ada dua alasan yang menyebabkan munculnya sikap apologetik terhadap negara Islam. ${ }^{24}$ Pertama,karena menguatnya apologi terhadap ideologi-ideologi Barat, seperti demokrasi, sosialisme, dan komunisme.Invasi kultural yang dilakukan Barat telah mempengaruhi seluruh sektor kehidupan, sehingga menimbulkan rasa rendah diri (inferiority complex) pada umat Islam.Hal ini kemudian melahirkan apresiasi ideologis yang bersifat totaliter kepada Islam, sehingga melahirkan cita-cita negara Islam.Kedua,legalisme.Legalisme telah membawa sebagian umat Islam pada paham apologetis negara Islam.Akibat dari legalisme adalah tumbuhnya apresiasi yang serba legalistis pada Islam, yang berbentuk 
penghayatan keislaman dengan gambaran bahwa Islam adalah struktur dan kumpulan hukum.Karena itulah, sebagian umat Islam sering menggambarkan ajaran Islam sebagai kumpulan hukum yang merupakan kelanjutan fiqih-isme.Karena dominannya pandangan fiqih-isme, makasegala bentuk reformasi selalu memusatkan sasarannyake bidang itu.Maka, negara Islammenjadi suatu apologi karena di dalamnya umat Islam berharap dapat menunjukkan aturan-aturan dan hukum-hukum lainnya.

Ulil menganjurkan bahwapenafsiran tekstual -yang masih dipertahankan oleh kelompok Islam radikal-terhadap ajaran Islam sudah harus ditinggalkan, karena ada banyak pandanganyang tadinya dianggap sebagai perintah agama, namun setelah ditelaah secara kritis dan mendalam, ternyata hal tersebut hanya merupakan ekspresi lokal dalam lingkup yang partikular dan terbatas, yang dewasa inisudahtidak relevan dengan perkembangan kehidupan modern, seperti pengharaman kepemimpinan perempuan dalam pemerintahan dan juga pelaksanaan hukum pidana Islam $(h u d u d)$, seperti potong tangan, cambuk, dan lontar batu.Bagi Ulil, persoalan wilayah ibadah murni, seperti salat, puasa, dllsudah tak perlu lagi diperdebatkan. Namun di luar wilayah itu, khususnya di bidang muamalah, persoalan penafsiran masih terbuka untuk didiskusikan dan diperdebatkan.

Agar ajaran Islam dapat selalu sejalan dengan perkembangan kehidupan manusia, makapenafsiran yang kontekstual menjadi sangat diperlukan.Untuk melakukan itu, makadiperlukan optimalisasi fungsi rasio atau akal.Ulil menyadari bahwasemua hal memang tak bisa dirasionalkan dalam Islam, namun itu tak berarti bahwa segalanyaharus dianggap sebagai perintah Tuhan yang tak bisa dirasionalkan. ${ }^{25}$ Islam memang berarti ketundukan, tetapi itu tak berarti bahwa setiap muslimharus sepenuhnya tunduk pada perintah Tuhan tanpareserve.Ajaran Islam adalah ajaran yang memberikan penghargaan pada penggunaanakal sebagaimanayang dikatakanUlil bahwa,

“...Dalam Quran sendiri, berkali-kali kita menjumpai ayat-ayat yang disudahi dengan sebuah pertanyaan retoris berbunyi "afala ta'qilun", apakah kalian tak memakai akal, atau "la'allakum tatafakkarun" atau "afala tatafakkarun", apakah kalian tak berpikir.

Ayat yang menarik perhatian saya sejak dulu adalah berikut ini, "inna syarra al- dawabbi 'inda al-Lahi al-shumm al-bukm al-lazina la ya'qilun." (QS 8:22). Terjemahan bebas ayat itu: seburuk-buruk binatang melata di muka bumi adalah orang-orang tuli dan bisu yang sama sekali tak memakai akal mereka.

Ayat di atas bukan semacam kutukan bagi mereka yang secara fisik menderita cacat tuli dan bisu. Dua kata itu dipakai dalam ayat di atas secara metaforis. Ayat itu sudah menjelaskan dirinya sendiri: tuli dan bisu di sana merujuk kepada orang-orang yang tak memakai akal. Yakni mereka yang hanya tunduk pada tradisi dan pemahaman yang sudah berlaku umum, tanpa memeriksa pemahaman itu secara kritis dengan akal sehat.,"26

Selama ini, sebagian umat Islam cenderung menempatkan teks agama dalam kedudukan yang sangat tinggi, sehinggamanusia sering terjebak dalam "penyembahan teks".Hal ini berdampak pada menurunnya daya tonjok psikologisumat Islam dalam 
memainkan perannya sebagai actor penafsir teks.Akhirnya teks agama menjadi kehilangan konteks. Ia hanya menjadi tumpukan kata dan kalimat yang hampa makna.

Ulil mengkritik kebekuan tersebut karena menurutnya ajaran Islam adalah ajaran yang optimistis dan apresiatif terhadap manusia yang ditunjukkan dalam konsep takrim atau pemuliaan manusia.Oleh karena itu, pandangan sebagian umat Islam yang menganggapbahwa posisi teks lebih tinggi daripada manusia harus dikritisi karenaiasangat bertentangan dengan prinsip dasar Al-Qur'an yang memberikan posisi yang tinggipada manusia dalam tugasnya sebagai khalifah di muka bumi. Atas dasar itulah - demikian Ulil-posisi manusia sudah seharusnya ditempatkansecara setara dengan teks, karena manusia-lah yang memberi makna pada teks melalui mediasi akal. Tanpa manusia, suatu teks tentu tak akan punya makna.Melalui mediasi akal itulah, manusia memainkan perannya untuk menyeberangi teks, agardapat menangkap visi etis Al-Qur'an dan meletakkannya kembali dalam proses dialog dengan kenyataan yang lebih kompleks dan selalu berubah-ubah.

\section{SIMPULAN}

Kehadiran Ulil Abshar Abdalla dalam meramaikan wacana keislaman di Indonesiadilatarbelakangi oleh adanya kegelisahan atas munculnya fenomena radikalisme agama di zaman reformasi di mana salah satu penyebabnya adalah kuatnya kecenderungan "penyembahan teks"pada umat Islam. Akibatnya, ajaran Islam yang menekankan pada kebebasan menjadi terabaikan karena konsentrasi umat Islam lebih banyak dihabiskanuntuk "menyembahteks". Bagi Ulil, kebebasan adalah suatu prinsip yang inheren dalam ajaran Islam karena ia memiliki landasan teologis dan historis.

Untuk mendekonstruksi kecenderungan "penyembahan teks" tersebut, maka diperlukan sebuah proses kontekstualisasi penafsiran yang sejalan dengan perkembangan riil kemanusiaan. Untuk itu, posisi manusia sudah saatnya di tempatkan secara setaradengan teks, karena ajaran Islam sangat optimistis dan apresiatif terhadap pemuliaan manusia.Dengan potensi akal yang dimiliki manusia sebagai pembeda antara dirinya dengan makhluk lain, maka manusiaseyogianya harus terlibat aktif dalam menangkap visi etis Al-Quran dan meletakannya kembali dengan proses dialog dengan kenyataan hidup yang lebih kompleks dan selalu berubah-ubah.

Apa yang dilakukan Ulil adalah sebuah respon anak zamannya terhadap persoalan logosentrisme yang telah berada padalevel yang mengkhawatirkan. Sebagai anak muda yang dibesarkan dalam iklim wacana postmodernisme yang ditandai dengan adanya relativisme dan pluralisme pemikiran, Ulil menggugat narasibesar dan juga penafsiran yang telah mapan dan terlembagakan, lalu menawarkan sebuah bentuk penafsiran baru,agarajaran Islam dapat sejalan dengan perkembangan kemanusiaan.

Gagasan yang dibawa oleh Ulil memang sangat menarik karena ia ditopang oleh berbagaidata dan referensi yang kayabaik dari Timur maupun Barat,sehingga mereka yang kurang mengikuti perkembangan wacana keilmuan (keislaman) akan sulit memahami jalan 
pikiran Ulil yang cenderungakademis dan borderless.Namun, setidaknya saya melihat bahwa respon umat Islam terhadap pemikiran Ulil cenderung menjadi terbelah di mana pemikiran Ulilcenderung kurang diapresiasioleh kelompok Islam radikal, yang pada umumnya memiliki basis massa yang kuat di kampus/universitas"sekuler". Hal tersebutdisebabkankarenawacana keislaman yang tumbuh di kampus "sekuler" cenderung hitam-putih dan monolitik. Sebaliknya, gagasan yang didengungkan olehUlil mendapatkan apresiasi yang cukup baikoleh kalangan kampus Islam, sepertiUIN dan sejenisnya.Itusebabnya, kalangan anti JIL menganggap bahwa kampus UIN telah terjangkiti oleh virus SEPILIS (Sekularisme, Pluralisme, Liberalisme).Pemikiran Ulil -bagi kalangan sivitas UIN-bukanlah sesuatu yang perlu dibesar-besarkan karena mereka umumnyatelah terbiasabersentuhan dengan berbagai keragaman dalam wacana keislaman.Bagi mereka, keragaman penafsiran pada teks agama merupakan hal yang wajar dan memiliki preseden sejarah.

Bila dilihat secara kritis, apa yang digagas oleh Ulil dalam pemikirannya bukanlah sesuatu yang baru karena ia hanya menampilkan kembali gagasan yang telah disiapkan landasan epistemogis dan teologisnya oleh para pemikir seperti Cak Nur, Gus Dur, Harun Nasution, Nasr Hamid Abu Zayd, dan beberapa bagian dari komunitas epistemikyang mewakili mazhab liberal, dalam kemasan yang lebih baru.Namun, apa yang dilakukan oleh Ulil tetap harus kita apresiasi karena ia telah menginjeksi umat Islam agar menghidupkan kembali kegairahan intelektual yang selama ini hilang dalam tubuh mereka.

\section{Endnote}

${ }^{1}$ Greg Fealy dan Anthony Bubalo,Jejak Kafilah: Pengaruh Radikalisme Timur Tengah di Indonesia,(Bandung: Mizan, 2005), h. 96-97.

${ }^{2}$ Ulil Abshar Abdalla, Menjadi Muslim dengan Perspektif Liberal, http://islamlib.com/?site=1\&aid=1252\&cat=content \&cid=13\&title=menjadi-muslim-dengan-perspektif-liberal, diakses pada tanggal 28 Mei 2015.

${ }^{3}$ Luthfi Assyaukanie, "Islam dan Liberalisme", dalam Hamid Basyaib (ed.), Membela Kebebasan: Percakapan tentang Demokrasi Liberal, (Cet. I., Jakarta: Pustakan Alvabet-Freedom Institute, 2006), h. 248.

${ }^{4}$ Harun Nasution, Islam Ditinjau Dari Berbagai Aspeknya (Jilid I), (Cet. 5., Jakarta: Penerbit Universitas Indonesia (UI-Press), 2011), h. 38-39.

${ }^{5}$ Harun Nasution, Islam Ditinjau Dari Berbagai Aspeknya (Jilid I), h. 38-39.

${ }^{6}$ Nurcholish Madjid, Islam, Kemodernan, dan Keindonesiaan,(Cet. I., Bandung: Mizan, 2008), h. 236.

${ }^{7}$ Nurcholish Madjid, Islam, Kemodernan, dan Keindonesiaan, h. 236-237

${ }^{8}$ Rizal Mallarangeng, Dari Langit: Kumpulan Esai tentang Manusia, Masyarakat, dan Kekuasaan. (Jakarta: KPG (Kepustakaan Populer Gramedia), 2008), h. 40.

${ }^{9}$ Ulil Abshar Abdalla, "Menyegarkan Kembali Pemahaman Islam”, Kompas, 18 November 2002. 
${ }^{10}$ Ulil Abshar Abdalla, "Menghindari "Bibliotratri": Tentang Pentingnya Menyegarkan Kembali Pemahaman Islam" dalam Komaruddin Hidayat dan Ahmad Gaus AF (ed.),Islam, Negara, dan Civil Society: Gerakan dan Pemikiran Islam Kontemporer, (Jakarta: Paramadina,2005), h. 415.

${ }^{11}$ Ulil Abshar Abdalla, "Menyegarkan Kembali Pemahaman Islam", Kompas, 18 November 2002.

${ }^{12}$ Ulil Abshar Abdalla, "Menyegarkan Kembali Pemahaman Islam”, Kompas, 18 November 2002.

${ }^{13}$ Ulil Abshar Abdalla, “Apa Setelah Nurcholish Madjid”, dalam Abdul Halim (ed.),Menembus Batas Tradisi, Menuju Masa Depan yang Membebaskan: Refleksi Atas Pemikiran Nurcholish Madjid (Cet.II., Jakarta: Kompas, 2006), h. 147.Bacajuga Nurcholish Madjid, Pintu-Pintu Menuju Tuhan, (Cet VIII., Jakarta: Paramadina-Dian Rakyat, 2008), h. 3-4.

${ }^{14}$ Ulil Abshar Abdalla, “Apa Setelah Nurcholish Madjid”, dalam Abdul Halim (ed.),Menembus Batas Tradisi, Menuju Masa Depan yang Membebaskan: Refleksi Atas Pemikiran Nurcholish Madjid. h. 147.

${ }^{15}$ Ulil Abshar Abdalla, "Atas Nama Umat Islam", dalam Hamid Basyaib dan Hamid Abidin (ed.), Mengapa Partai Islam Kalah: Perjalanan Politik Islam dari Pra-Pemilu '99 sampai Pemilihan Presiden. (Cet. I., Jakarta: Alvabet, 1999), h. 258-260.

${ }^{16}$ Abdurrahman Wahid,Islamku Islam Anda Islam Kita: Agama Masyarakat Negara Demokrasi, (Cet., II Jakarta: The Wahid Institute, 2006), h. 144.

${ }^{17}$ Abdurrahman Wahid, Islamku Islam Anda Islam Kita: Agama Masyarakat Negara Demokrasi, h. 144145.

${ }^{18}$ Abdurrahman Wahid, Islamku Islam Anda Islam Kita: Agama Masyarakat Negara Demokrasi, h. 144145.

${ }^{19}$ Ulil Abshar Abdalla, "Islam dan Kebebasan", dalam dalam Hamid Basyaib (ed.), Membela Kebebasan: Percakapan tentang Demokrasi Liberal, (Cet. I., Jakarta: Pustakan Alvabet- Freedom Institute, 2006), h. 223-224.

${ }^{20}$ Ulil Abshar Abdalla, "Islam dan Kebebasan", dalam Hamid Basyaib (ed.), Membela Kebebasan: Percakapan tentang Demokrasi Liberal, h. 225.

${ }^{21}$ Ulil Abshar Abdalla, "Islam dan Kebebasan", dalam Hamid Basyaib (ed.), Membela Kebebasan: Percakapan tentang Demokrasi Liberal, h. 225.

${ }^{22}$ Ulil Abshar Abdalla, "Menyegarkan Kembali Pemahaman Islam”, Kompas, 18 November 2002.

${ }^{23}$ Ulil Abshar Abdalla, "Menyegarkan Kembali Pemahaman Islam”, Kompas, 18 November 2002.

${ }^{24}$ BacaNurcholish Madjid, Islam, Kemodernan, dan Keindonesiaan, (Cet. I., Bandung: Mizan, 2008), h. 293-296.

${ }^{25}$ Ulil Abshar Abdalla, Menjadi Muslim dengan Perspektif Liberal, http://islamlib.com/?site=1\&aid=1252\&cat=content\&cid=13\&title=menjadi-muslim-dengan-perspektif-liberal, diakses pada tanggal 28 Mei 2015.

${ }^{26}$ Ulil Abshar Abdalla, Menjadi Muslim dengan Perspektif Liberal, http://islamlib.com/?site=1\&aid=1252\&cat=content\&cid=13\&title=menjadi-muslim-dengan-perspektif-liberal, diakses pada tanggal 28 Mei 2015. 


\section{DAFTAR PUSTAKA}

Abdalla, Ulil Abshar."Menyegarkan Kembali Pemahaman Islam”.Kompas, 18 November 2002.

Menjadi Muslim dengan Perspektif Liberal. http://islamlib.com/?site=1\&aid=1252\&cat=content $\&$ cid=13\&title=menjadimuslim-dengan-perspektif-liberal, diakses pada tanggal 28 Mei 2015.

"Menghindari "Bibliotratri": Tentang Pentingnya Menyegarkan Kembali Pemahaman Islam", dalam Komaruddin Hidayat dan Ahmad Gaus AF (ed.). Islam, Negara, dan Civil Society: Gerakan dan Pemikiran Islam Kontemporer. Jakarta: Paramadina, 2005.

. "Apa Setelah Nurcholish Madjid”, dalam Abdul Halim (ed.).Menembus Batas Tradisi, Menuju Masa Depan yang Membebaskan: Refleksi Atas Pemikiran Nurcholish Madjid. Cet.II., Jakarta: Kompas, 2006.

. “Atas Nama Umat Islam", dalam Hamid Basyaib dan Hamid Abidin (ed.). Mengapa Partai Islam Kalah: Perjalanan Politik Islam dari Pra-Pemilu '99 sampai Pemilihan Presiden. Cet. I., Jakarta: Alvabet, 1999.

.Islam dan Kebebasan", dalam dalam Hamid Basyaib (ed.).Membela Kebebasan: Percakapan tentang Demokrasi Liberal.Cet. I., Jakarta: Pustakan Alvabet- Freedom Institute, 2006.

Assyaukanie, Luthfi."Islam dan Liberalisme”, dalam Hamid Basyaib (ed.).Membela Kebebasan: Percakapan tentang Demokrasi Liberal.Cet. I., Jakarta: Pustaka Alvabet- Freedom Institute, 2006.

Fealy, Greg dan Anthony Bubalo.Jejak Kafilah: Pengaruh Radikalisme Timur Tengah di Indonesia.Bandung: Mizan, 2005.

Madjid, Nurcholish.Islam, Kemodernan, dan Keindonesiaan. Cet. I., Bandung: Mizan, 2008.

Madjid, Nurcholish.Pintu-Pintu Menuju Tuhan. Cet VIII., Jakarta: Paramadina-Dian Rakyat, 2008.

Mallarangeng, Rizal.Dari Langit: Kumpulan Esai tentang Manusia, Masyarakat, dan Kekuasaan. Jakarta: KPG (Kepustakaan Populer Gramedia), 2008. 
Nasution, Harun. Islam Ditinjau Dari Berbagai Aspeknya (Jilid I). Cet. 5.,Jakarta: Penerbit Universitas Indonesia (UI-Press), 2011.

Wahid, Abdurrahman.Islamku Islam Anda Islam Kita: Agama Masyarakat Negara Demokrasi. Cet.II.,Jakarta: The Wahid Institute, 2006. 